\title{
MANDAMUS IN ADMINISTRATIVE ACTIONS: CURRENT APPROACHES
}

In 1972, the ministerial-discretionary distinction, described as the "mischievous dichotomy"1 and widely criticized, ${ }^{2}$ remained the major problem area under the Mandamus and Venue Act of $1962 .^{3}$ Recent cases involving mandamus with respect to administrative action reveal that courts are split in their approaches as to when inandamus may lie. Many courts follow the traditional ministerialdiscretionary distinction and indicate that mandamus is proper only if there is a ministerial duty imposed by law. Other courts, departing from the rigid ministerial-discretionary distinction, indicate that mandamus will lie even in a case involving a discretionary duty when the permissible scope of discretion has been exceeded. ${ }^{4}$

Mandamus is a judicial command requiring the performance of a specified duty which has not been performed. ${ }^{5}$ Originally a common law writ, mandamus has been used by American courts to review administrative action. ${ }^{6}$ Over forty years ago the Supreme Court gave a classic explanation of the use of mandamus:

Mandamus is employed to compel the performance, when refused, of a ministerial duty, this being its chief use. It is also employed to compel action, when refused, in matters involving judgment and discretion, but not to direct the exercise of judgment or discretion in a particular way, nor to direct the retraction or reversal of action already taken in the exercise of either. ${ }^{7}$

Although in 1937 the Federal Rules of Civil Procedure technically abolished the writ of mandamus, ${ }^{8}$ it is clear that similar relief, an

1. Byse \& Fiocca, Section 1361 of the Mandamus and Venue Act of 1962 and "Nonstatutory" Judicial Review of Federal Administrative Action, 81 HARV. L. REv. 308, 316 (1967).

2. See note 23 infra and accompanying text.

3. 28 U.S.C. $\S \S 1361,1391(\mathrm{e})(1970)$.

4. See note 42 infra.

5. JAFFE 176.

6. W. Gellhorn \& C. Byse, Administrative Law, Cases and Comments 119-20 (5th ed. 1970). Originally, mandamus was a writ issued by judges of the King's Bench in England. American courts, as inheritors of the judicial power of the King's Bench, adopted the use of the writ. Id.

7. Wilbur v. United States ex rel. Kadrie, 281 U.S. 206, 218 (1930). See also Jacoby, The Effect of Recent Changes in the Law of "Nonstatutory" Judicial Review, 53 GEO. L.J. 19, 25-26 (1964).

8. Scire Facias and Mandamus. The writs of scire facias and mandamus are abolished. Relief heretofore available by mandamus or scire facias 
action in the nature of mandamus, is still available; ${ }^{9}$ Rule $81(\mathrm{~b})$ specifically provides that the relief previously available under the writ of mandamus may still be obtamed. ${ }^{10}$ Apparently, the mandamus relief presently available is granted or withheld under the same principles that governed the former common-law writ.11 Under this traditional approach, mandamus will lie only if the duty of the officer is ministerial-a duty positively commanded, plainly defined, and peremptory. ${ }^{12}$ If the duty is determined to be discretionaryallowing some exercise of judgment-mandamus is improper. ${ }^{13}$

Prior to 1962, except for the District Court for the District of Columbia, ${ }^{14}$ federal courts had no jurisdiction to issue original writs of mandumus. ${ }^{15}$ As a result, parties throughout the country seeking mandamus relief, including rehef in response to federal administrative action, were forced to bring suit in the District of Columbia. In 1962 Congress enacted section 1361 of the Judicial Code, The Mandamus and Venue Act, which provides:

The district courts shall have original jurisdiction of any action in the nature of mandamus to compel an officer or employee of the Umited States or any agency thereof to perform a duty owed to the

may be obtained by appropriate action or by appropriate motion under the practice prescribed in these rules. FED. R. Civ. P. 81(b).

9. E.g., Finley v. Chandler, 377 F.2d 548 (9th Cir.), cert. denied, 389 U.S. 869 (1967); Hammond v. Hull, 131 F.2d 23, 25 (D.C. Cir. 1942), cert. denied, 318 U.S. 777 (1943).

10 Sce note 8 supra.

11. 3A W. Barron \& A. Holtzofr, Federal Practice and Procedure § 1692 at 169 (Wright ed. 1958). See generally H. Hart \& H. WeChSLER, The Federal COURTS AND THE FEDeral SYSTEM 1377-85 (2d ed. 1973).

12. See, e.g., Thomas v. Vinson, 153 F.2d 636, 638-39 (D.C. Cir. 1946); United States ex rel. Roughton v. Ickes, 101 F.2d 248, 252 (D.C. Cir. 1938).

13. See note 20 infra and accompanying text.

14. In Kendall v. United States ex rel. Stokes, 37 U.S. (12 Pet.) 522 (1838), the Supreme Court held that the Circuit Court of the District of Columbia, then a court of original and appellate jurisdiction, had jurisdiction to issue original writs of mandamus. The Court stated in support that the Act of February 27, 1801, ch. $15, \S 1,2$ Stat. 103, provided that the laws of Maryland were to continue in force in that part of the District of Columbia given by Maryland to the United States, id. at 619-20, and that the laws of Maryland authorized writs of mandamus to compel an executive officer to perform a ministerial act. Id. at 621. See generally Byse \& Fiocca, supra note 1, at 310-12. For the historical development of the federal court system, see H. Hart \& H. Wechsler, The Federal Courts and the Federal System 32-49 (2d ed. 1973); Surrency, $A$ History of the Federal Courts, 28 MO. L. REv. 214 (1968).

15. An 1813 Supreme Court case, M'Intire v. Wood, 11 U.S. (7 Cranch) 504 held that the Judiciary Act of 1789 did not grant jurisdiction to lower federal courts to issue original writs of mandamus. 3 DAvis $\$ 2310$, at 336 . 


\section{plaintiff. ${ }^{16}$}

Section 1361 gives each federal district court subject matter jurisdiction of any action in the nature of mandamus and the express power to compel a government official or agency to perform an affirmative duty. ${ }^{17}$ The purpose of section 1361 was not to expand judicial review of federal administrative action, ${ }^{18}$ but merely to make mandamus relief available in federal district courts throughout the country, thus alleviating the inconvemence of brimging an action only in the District of Columbia. ${ }^{10}$ However, by extending the power to issue original writs of mandamus throughout the federal court system, the Mandamus and Venue Act forced all district courts to contend with the traditional difficulties of mandamus.

Courts have adopted two approaches in construing the duty element required for mandamus under section 1361. Under the first approach, the court makes the traditional determination of whether the alleged duty is ministerial or discretionary. If the duty is determined to be ministerial in nature, mandamus will issue. However, if the adinimistrative action sought to be compelled is found to be discretionary, the court will find itself lacking in jurisdiction under section 1361. This first approach seems to lrave been approved by many courts which have dealt with the problem in recent years. ${ }^{20}$ In some of these decisions, courts have specifically

16. 28 U.S.C. $\$ 1361$ (1970). For insight into mandamus in state courts, see Norvell \& Sutton, The Original Writ of Mandamus in the Supreme Court of Texas, 1 St. MARy's L.J. 177 (1969); Comment, Noteworthy Developments in California's Administrative Mandamus, 8 CALIF. WEST. L. REV. 301 (1972).

17. When the bill was being considered, the Justice Department proposed a draft which was different in an essential respect. Instead of the words "duty owed to the plaintiff," 28 U.S.C. \& 1361 (1970), the Jnstice Department bill contained the words "a ministerial duty owed to the plaintiff under a law of the United States." S. REP. No. 1992, 87th Cong., 2d Sess. 7 (1962). The Justice Department's proposed bill would have, in effect, directly and positively incorporated the traditional ministerial-discretionary distinction into section 1361 . The sponsors feared that the proposed insertion of the word "ministerial" would resurrect the ministerial-discretionary distinction, Byse \& Fiocca, supra note 1, at 316; and the bill passed into law without the insertion. Id. at 317-18; see 108 CONG. REC. 20079 (1962). For a discussion of the legislative history of section 1361, see Byse \& Fiocca, supra note 1, at 313-18; Jacoby, supra note 7, at 20-23.

18. Byse \& Fiocca, supra note 1, at 319. See Jacoby, supra note 7, at 21-22.

19. See id. at 19.

20. Within the last three years, a significant number of courts have denied mandanus under section 1361 in opinions which indicated that mandainus could be employed only to compel an administrator to perform a duty that is ministerial in nature. Keeny v. Secretary of the Army, 437 F.2d 1151 (8th Cir. 1971) (former serviceman brought action to compel correction of his military record); Yahr v. 
indicated that the ministerial duty requirement precludes judicial review under section 1361 even if an administrator abuses his discretion. $^{21}$

Under the second approach adopted by courts when construing the duty element for mandamus, the court first determines whether the duty alleged to be owed is ministerial or discretionary. If the duty is found to be ministerial in nature, mandamus will lie as in the first approach. However, even if the duty is found to be discretionary, the court will further determine whether, by failing to perform the duty, the administrator exceeded the permissible scope of his discre-

Resor, 339 F. Supp. 964 (E.D.N.C. 1972) (servicemen brought action for injunction forbidding prohibition of right to hold meetings on military reservation and right to distribute materials in opposition to Viet Nam war); Still v. Commanding Officer, U.S. Army Reserve Center, 334 F. Supp. 617 (N.D. Ala. 1971), vacated on other grounds, 463 F.2d 991 (5th Cir. 1972) (reservist brought action to challenge denial of his application for discharge from Army as a conscientious objector); Schmidt v. Laird, 328 F. Supp. 1009, 1011 (E.D.N.C. 1971) (serviceman brought action for discharge from Army as a conscientious objector); Bass Angler Sportsman Soc'y v. United States Stcel Corp., 324 F. Supp. 412, 416 (N.D. Ala.), aff'd sub nom. Bass Anglers Sportsman Soc'y, Inc. v. Koppers Co., 447 F.2d 1304 (5th Cir. 1971) (fishing association brought action to require Secretary of Army and Chief of Corps of Engineers to establish and apply standards for issuance of permits allowing deposit of refuse into navigable waters). Cf. McQueary v. Laird, 449 F.2d 608 (10th Cir. 1971) (resident of Rocky Mountain Arsenal area brought class action to enjoin storage of chemical and biological warfare agents). Sec also Iowa City-Montezuma R.R. Shippers Ass'n v. United States, 338 F. Supp. 1383, 1387 (S.D. Iowa 1972) (plaintiff sought jurisdiction under 28 U.S.C. $\& 1651$ (a) (1970), and not under section 1361).

Some cases state that mandamus will not lie if the action sought to be compelled is discretionary in nature. Yahr v. Resor, 339 F. Supp. 964 (E.D.N.C. 1972); Schmidt v. Laird, 328 F. Supp. 1009 (E.D.N.C. 1971); Langston v. Ciccone, 313 F. Supp. 56, 60 (W.D. Mo. 1970) (federal convict sought release from custody of director of United States Medical Center for Federal Prisoners, alleging lack of due process in the revocation of his parole).

21. Jarrett v. Resor, 426 F.2d 213, 216-17 (9th Cir. 1970); accord, Gonzales Salcedo v. Lauer, 430 F.2d 1282 (9th Cir. 1970); Yahr v. Resor, 339 F. Supp. 964 (E.D.N.C. 1972).

The Jarrett court stated:

The complaint in this action does not allege that defendants have failed to fulfill a plainly described ministerial duty. It alleges at most that in fulfilling their duty of acting upon his request for a discharge froin the Army, they either abused their discretion, incorrectly found the facts, or misapplied the law. It follows that neither on its face nor in substance, can the complaimt be regarded as invoking jurisdiction under section 1361. 426 F.2d at 216-17 (emphasis added).

For authority indicating that an abuse of discretion may be remedied by mandamus see W. Gellhorn \& C. Byse, Administrative Law, Cases and Comments 120 (5th ed. 1970); JAFFe 182. Arguably courts utilizing the second approach (see notes 22-23 infra and accompanying text) are making a determination of whether or not there has been an abuse of discretion. See note 38 infra. 
tion. ${ }^{22}$ The court will typically examine the statute granting the authority to the administrator, the congressional purpose, and other data such as the pertinent administrative regulations, $\mathrm{m}$ order to delineate the boundaries within which the officer may permissibly exercise his discretion; if those bounds are exceeded, mandamus will hie. ${ }^{23}$

A 1972 district court case clearly deınonstrates that a court utilizing the first approach will consider itself to be without subject matter jurisdiction if no ministerial duty is shown, even though an abuse of discretion is indicated. In Yahr v. Resor, ${ }^{24}$ plaintiff soldiers brought an action for mandamus against the Secretary of the Army and the Commanding General of Fort Bragg, alleging that they were being deprived of certain First Amendment rights ${ }^{25}$ under allegedly unconstitutional military regulations. ${ }^{26}$ After noting that the military regulations had previously been declared constitutional, ${ }^{27}$ the District Court for the Eastern District of North Carolina held that it was without subject matter jurisdiction under section 1361. The court stated that before mandamus may issue it must be clear that the duty of the federal officer "be mimisterial, plainly defined, and peremptory."28 The court then stated that although an abuse of discretion is a legally cognizable wrong, a writ of " $[\mathrm{m}]$ andamus is not a proper remedy to challenge abuse of discretion." 29 Thus, in Yahr, the court was unwilling to examine the action of the federal officer even to determine whether he had acted arbitrarily and abused his discretion; the court found itself without jurisdiction under section 1361 because the actions complained of were committed in the exercise of a discretionary function and were not "merely ministerial involving a clear and peremptory duty to plaintiffs." ${ }^{30}$ Under the first ap-

22. See note 42 infra and accompanying text.

23. The commentators have shown near unanimity in advocating an examination of the scope of discretion employed in the second approach. Byse \& Fiocca, supra note 1 , at $333-34 ; 3$ Davis $\$ 23.11$, at $360-61$ (advocating the use of equitable principles to determine scope of review); JAFFE 181-83. Likewise, the commentators uniformly criticize the ministerial-discretionary distinction employed in the first approach. Byse \& Fiocca, supra note 1, at 333-34; 3 Davis $\$ 23.12$, at 361; JAFFE 181.

24. 339 F. Supp. 964 (E.D.N.C. 1972).

25. Plaintiffs alleged that they were demied the right to hold public meetings and distribute anti-war materials on the military reservation. $I d$. at 966.

26. $I d$.

27. Id. at 967.

28. Id.

29. Id. See note 21 supra.

30. 339 F. Supp. at 967. 
proach, as set out by the Yahr case, even if an administrator were clearly to act in a manner inconsistent with the powers granted to his discretion, inandamus would not he.

The second approach was employed in 1972 by the Second Circuit Court of Appeals in Lovallo v. Froehlke. ${ }^{31}$ Lovallo, a soldier, petitioned for a writ of habeas corpus to compel the Army to discharge him as a conscientious objector. ${ }^{32}$ When the District Court for the Southern District of New York granted the writ, the Army placed Lovallo on leave status ${ }^{33}$ and appealed the adverse decision. The Second Circuit subsequently reversed and dismissed the petition..$^{34}$ For several months after the appellate decision, the Army failed to order Lovallo back to active duty; ${ }^{35}$ however, such an order was issued one day after Lovallo's original term of enlistment had expired. ${ }^{38}$ The Army contended that the leave period was excludable from and would not count toward fulfillment of plaintiff's obligated term of duty. The plaintiff thereupon brought an action for mandainus to compel the Secretary of the Army to order his discharge. The court indicated that the question in the case was whether the three month delay in the issuance of the Army orders was an abuse of discretion so gross as to justify issuance of a writ of mandanus to release him; ${ }^{37}$ the court held that it was not. ${ }^{38}$ Unlike the court in Yahr, the court did not merely utilize the traditional ministerial-discretionary approach; rather, it made a determination of the permissible scope of discretion. ${ }^{39}$ In so doing, the Lovallo court

31. 468 F.2d 340 (2d Cir. 1972).

32. Id. at 341 .

33. See id. at 341-42. Contrary to the order of the appellate court that he was to "remain on leave status," id, the Army subsequently ordered Lovallo "released from the custody and control of the Army" without granting him a discharge; therefore, Lovallo "found himself out of the Army, 'released from military control,' though without being released from active military duty or discharged to reserve status." Id. at 343.

34. Lovallo v. Resor, 443 F.2d 1262 (2d Cir. 1971).

35. Lovallo was on leave status for more than six months after the habeas corpus order was reversed. 468 F.2d at 346.

36. Id. at 343 .

37. $I d$.

38. Id. at 346. The court stated that the Army's inaction was sensible during the ninety days following the court's reversal of the habeas order, the period during which Lovallo could have petitioned for certiorari. Id.

39. Id. at 345-46. The court cited Umited States ex rel. Schonbrun v. Commanding Officer, 403 F.2d 371 (2d Cir. 1968), cert. denied, 394 U.S. 929 (1969), for the proposition that the court would not "undertake 'civilian review of discretionary action by the military' in so-called "hardship cases.'" 468 F.2d at 344. However, the court noted that Schonbrun was distinguishable. Since the court 
looked to the relevant circumstances ${ }^{40}$ in determining that the issuance of Army orders was an act within the permissible bounds of discretion. ${ }^{41}$ This second approach typifies the reasoning utilized in recent Second Circuit cases, ${ }^{42}$ as well as in several cases decided out-

might "properly examine whether the Army has followed its own regulations" it could certainly determine the effect of the court's own mandate, the dismissal of the habeas corpus appeal. Id.

40. In determining that the discretion granted to the Secretary of the Army had not been abused, the court looked to the plaintiff's oath of enlistment, a statute defining active duty, and the effect of the delay on the plaintiff. Id. at 345-46.

41. In addition, the Court recommended the formulation of an army regulation prescribing the procedure for recall of a soldier who was granted a writ of habeas corpus which was later reversed on appeal. Id. at 346.

42. A series of recent decisions in the Second Circuit has indicated, at least in dicta, adherence to the second approach. In Casarino v. United States, 431 F.2d 775 (2d Cir. 1970), the court of appeals indicated that the standard of "rational exercise" would be utilized to ascertain whether or not a discretionary action was beyond the reach of mandamus under section 1361. The court held that an Air Force decision to call the plaintiff physician to active duty as a general nedical officer was within the province of a "rational exercise of discretion," and declined to grant rehief. Id. at 777.

In Nixon v. Secretary of Navy, 422 F.2d 934 (2d Cir. 1970), a Navy enlisted nuan brought an action for inandaunus to cancel an enlistment extension agreenent, alleging that he had received none of the benefits for which the extension was executed. Denying relief, the court held that the ruling of the Chief of Naval Personnel in denying the cancellation was not so arbitrary as to justify judicial intervention. The court, however, expressed the caveat that official military conduct may "go so far beyond the limits of what may be considered a rational exercise of discretion as to call for mandamus." Id. at 939 . In its determination of whether or not mandainus would lie, the court viewed rationality as the standard against which to measure the exercise of discretion. See also Feliciano v. Laird, 426 F.2d 424 (2d Cir. 1970); Stone v. Jennings, 318 F. Supp. 1379 (S.D.N.Y. 1970).

In Leonhard v. Mitchell, - F.2d - (2d Cir. 1973), a divorced husband brought an action for mandamus to compel a Justice Department attorney, who had arranged secret relocation and new identities for the husband's former wife and children after the wife's new husband testified against members of an organized crime syndicate, to disclose to the former husband the new location and identities of his children. The Second Circuit Court of Appeals stated that while traditionally nıandamus was appropriate to compel officials to comply with the law only when no discretion was involved in that compliance, decisions construing section 1361 lave also leld that official conduct can go so far beyond any rational exercise of discretion as to call for mandamus. Therefore, the court must determine the scope of discretion when considering a request for rehef under section 1361. The court, however, denied relief because section 1361 requires a duty owed by a government official. The husband had relied only upon the due process clause of the fifth amendment to establish the duty, claiming that the clause protects the biberty of parents to raise their children as they see fit, free from federal interference. The court stated that this contention went too far, id. at -, and that having found no violation of statutory or constitutional rights, $i d$. at $\rightarrow$, a federal court is without jurisdiction to issue a mandamus order. Id. at -

In Fifth Avenue Peace Parade Comm. v. Hoover, 327 F. Supp. 238 (S.D.N.Y. 
1971), a district court denied the defendant's motion to dismiss an action for the return of copies of plaintiff's checks and back records seized by the FBI. In denying the existence of jurisdiction under a section 1361 mandanus theory, the court stated that "[n]ormally, acts of discretion are not subject to nuandamus, although officials may occasionally go so far beyond their discretion as to warrant judicial interference." Id. at 242 (eniphasis added). The court thus evidenced a willingness to look beyond the determination of whether an administrative action was ininisterial or discretionary and to exanine the scope of discretion to determine if the act sought to be conipelled was outside that scope. The court nevertheless revealed a sinultaneous recognition of the traditional theory, stating that inandamus under section 1361 was appropriate "only to review ministerial acts . . . "Id.

In Cortright v. Resor, 325 F. Supp. 797 (E.D.N.Y. 1971), mandamus was ordered by a district court to cancel the transfer orders of niembers of the U.S. Army Band who alleged they were transferred as a result of their antiwar activity. The court stated that discipline which was otherwise lawful becoines illegal when utilized to suppress first amendment (free speech) rights. In response to the defense that no niandamus jurisdiction existed because the actions complained of were discretionary, the court answered:

It is equally well established that mandamus nuay be used to correct abuse of discretion by a federal officer, particularly if the abuse constitutes a violation of constitutional rights.

The instant action has at its heart allegations that military officers acted so as to violate [plaintiff's] constitutional rights .... If these allegations have merit, the military officers acted outside the scope of their discretionary authority. 1d. at 812 (citations omitted).

The district court indicated that an examination of the scope of discretion of the Secretary of the Army was proper, that this examination revealed that the limits of his discretion had been exceeded, and that mandamus was proper to reverse his action, albeit discretionary. The court of appeals, however, reversed. Cortright v. Resor, 447 F.2d 245 (2d Cir. 1971), cert. denied, 405 U.S. 965 (1972). In an opinion that likewise recognized that a determination of the scope of discretion was necessary, the court held that this scope had not been exceeded. The court recognized that Army personnel bad a right of protest, but that the Army likewise had a right to nuaintain the effectiveness of its nilitary units. The court of appeals reversed because it felt that the Army had a "Iarge scope" of discretion in striking a balance between the conflicting rights and that the Army had not overstepped its "bounds." Id. at 255.

A careful reading of these cases indicates that a strong argument can be made that phrases such as action beyond a "rational exercise of discretion," acts "beyond their discretion," and action "outside the scope" of discretionary authority, are used synonymously with "an abuse of discretion." Although Byse and Fiocca, supra note 1 , at $335 \mathrm{n} .99$, recognize the "difficult subtle and controversial questions that he behind the expression 'scope of the delegated power' (or 'authority' or 'discretion')," id. at $335 \mathrm{n} .99$, they too have employed "abuse of discretion" where "action beyond the scope of discretion" would seemingly be equally applicable. 1d. at 350. For example, courts which have defined "abuse of discretion" in the context of mandamus have indicated that the writ will issue to correct "an abuse of discretion," which is "not the exercise of discretion, but action beyond the limits of discretion." Palmer v. Fox, 118 Cal. App. 2d 453, 456, 258 P.2d 30, 33 (Dist. Ct. App. 1953); accord, Browning v. Dow, 60 Cal. App. 680, 682, 213 P. 707, 708 (Dist. Ct. App. 1923). What is most significant, however, is that no matter what term a particular court utilizes in its examination, courts utilizing the second approach examine the extent of permissible discretion, whereas courts utilizing the first approach do not. 
side the Second Circuit. ${ }^{43}$

When faced with actions for mandamus under section 1361, courts should employ the second approach-looking beyond a mere determmation of whether the duty owed is within the discretion of the administrator and deciding whether the scope of discretion has been exceeded. Professor Davis has argued that

43. A small number of cases outside the Second Circuit involving mandamus under section 1361 have demonstrated a willingness to utilize the second approach. The Court of Appeals for the District of Columbia Circuit in Peoples v. USDA, 427 F.2d 561 (D.C. Cir. 1970), held that poor people in the State of Alabama were entitled to maintain an action against the Department of Agriculture to raise objections to the administration of the Food Stamp Act of 1964. The court interpreted section 1361 as permitting district courts generally to issue corrective orders when federal officials are not acting "within the zone of their permissible discretion but are abusing their discretion ..., " id. at 565, and remanded the case to the district court to rule on the "nature and scope" of the Secretary of Agriculture's discretion. $I d$. at 566. The district court was further instructed that even if it should conclude that the matter involved was committed to the discretion of the Secretary, the district court should also express its views as to whether the Secretary's exercise of discretion was consistent with the pertinent statute and the Constitution in the event the exercise of discretion is held subject to judicial review. Id. The Peoples court thus indicated that an examination of the scope of discretion of the administrator was necessary; in a supplemental opinion, however, the court of appeals backed off considerably. In response to the defendant's contention that if it were determmed that Congress had committed the administration of the Food Stamp Program to the Secretary, a ruling as to whether he exercised proper discretion would be unnecessary, the court issued a supplemental opinion and held that the district court's view on the clain of abuse of discretion was "not . . . imperative." Id. at 567. Although clouded by the supplemental opinion, Peoples can fairly be read to support the position that a court must not merely determine whether an action is ministerial or discretionary, but should also determine, if the act sought to be compelled or retracted is discretionary, the permissible scope of discretion. By using the language "where Federal officials are not acting within the zone of their permissible discretion but are abusing their discretion or otherwise acting contrary to law ..."id. at 565, the Peoples court also gave weight to the argument that action outside the "zone of permissible discretion," at least in the context of an action for inandamus, may be synonymous with an "abuse of discretion." See note 42 supra.

A Third Circuit case, Davis v. Shultz, 453 F.2d 497 (3d Cir. 1971), indicated a similar willingness to examine the scope of discretion of an administrator (the Secretary of Labor), and it affirmed the dismissal of an action brought by a discharged Neighborhood Youth Corps trainee. The court stated that the "plaintiff has claimed no such variance from the permissible scope of discretion granted to [the] Secretary .... Id. at 502. The court also indicated, without citation, that "[t]he majority view is that in certain limited cases a $\$ 1361$ action may be used to compel the performance of an act committed to discretion." Id.

A recent Fourth Circuit decision, Burnett v. Tolson, No. 72-1545 (4th Cir., Feb. 21, 1973), stated in dictum that determining a particular duty to be discretionary "does not necessarily resolve the question of the availability of mandamus." Id. at 9 n.8. Terming the ministerial-discretionary diclotoiny as "not very helpful in analysis," id. at 12 , the court seemed to be rejecting the first approach. 
[t]he law resting upon the ministerial discretionary distinction is ... undesirable in that it prevents the use of judicial skills on the very questions of interpretation on which those skills are most needed ....44

When a mandamus action under section 1361 is brought, a court necessarily must resolve whether the action in question is ministerial or discretionary. The distinction itself is often not clearly defined, for, while almost all administrative actions imvolve some elements of discretion, few are entirely discretionary;"45 a court which has adopted the first approach, purporting to grant relief only when the duty is ministerial, would seem to be restricting mandamus to those situations where the duty is only slightly or insubstantially discretionary. Since this ministerial-discretionary determination must be made in all cases, it would require little additional effort to delineate-once the act sought to be compelled or retracted is found discretionary in naturethe permissible scope of discretion, and to determine whether that scope has been exceeded.

A judicial determination of the permissible scope of discretion would be beneficial in several respects. First, this determination would set out the parameters of the scope of action and woult thereby establish guidelines for future conduct. Second, if the permissible scope has been exceeded, a remedy can be afforded an injured litigant who might otherwise be denied one. Also, in most cases, petitioners do not allege that the defendant official was granted no discretion, but rather that the withholding of the relief sought by the petitioner is an improper use of the discretion granted; courts utilizing the first approach never reach this question. ${ }^{46}$ The proper qucstion for

44. 3 Davis $\$ 23.11$, at 354 (1958). Professor Jaffe has commented: "[T]he notion that each administrative act can be classified a priori either as 'ministerial' or 'discretionary' is unsound and unworkable." JAFFE 181. Byse and Fiocca have stated that "[p]erhaps the most effective step in the development of a rational law of mandamus would be judicial rejection or abandonment of the ministerialdiscretionary distinction ...." Byse \& Fiocca, supra note 1, at 334 .

45. "As a mode of analysis, the ministerial-discretionary dichotomy is largely illusory because there are few federal administrative determinations that do not involve an element of discretion and few that are wholly discretionary." Byse \& Fiocca, supra note 1, at 333 . Professor Jaffe is in agreement: "The classification is illusory .... .

. . . Most powers to act involve some elements of choice if only as to detail. On the other hand, nearly all powers to act, however numerous and broad the considerations relevant to choice, exclude and deny the legahty of other elements as factors of choice." J J 181.

46. Byse \& Fiocca, supra note 1 , at 334 . 
the court to decide in its determination of whether to grant relief to the aggrieved party, therefore, is not whether the duty owed is discretionary, but whether the refusal to act is within the permissible realm of the discretion granted to the administrator. ${ }^{47}$

47. Professor Davis contends that in general "the greatest and most frequent injustice occurs at the discretion end of the scale . . .."K. DAVIS, DiscretionarY JUSTICE $v$. (1969). 